\title{
A Novel Approach to Analyze Membrane Proteins by Laser Mass Spectrometry: From Protein Subunits to the Integral Complex
}

\author{
Nina Morgner, ${ }^{a}$ Thomas Kleinschroth, ${ }^{\mathrm{b}}$ Hans-Dieter Barth, ${ }^{\mathrm{a}}$ \\ Bernd Ludwig, b,c and Bernhard Brutschy ${ }^{\mathrm{a}}$ \\ ${ }^{a}$ Institute for Physical and Theoretical Chemistry, Johann Wolfgang Goethe University, Frankfurt am Main, \\ Germany \\ ${ }^{b}$ Molecular Genetics Group, Institute of Biochemistry, Johann Wolfgang Goethe University, Frankfurt am \\ Main, Germany \\ "Centre of Excellence "Macromolecular Complexes," Johann Wolfgang Goethe University, Frankfurt am \\ Main, Germany
}

\begin{abstract}
A novel laser-based mass spectrometry method termed LILBID (laser-induced liquid bead ion desorption) is applied to analyze large integral membrane protein complexes and their subunits. In this method the ions are IR-laser desorbed from aqueous microdroplets containing the hydrophobic protein complexes solubilized by detergent. The method is highly sensitive, very efficient in sample handling, relatively tolerant to various buffers, and detects the ions in narrow, mainly low-charge state distributions. The crucial experimental parameter determining whether the integral complex or its subunits are observed is the laser intensity: At very low intensity level corresponding to an ultrasoft desorption, the intact complexes, together with few detergent molecules, are transferred into vacuum. Under these conditions the oligomerization state of the complex (i.e., its quaternary structure) may be analyzed. At higher laser intensity, complexes are thermolyzed into subunits, with any residual detergent being stripped off to yield the true mass of the polypeptides. The model complexes studied are derived from the respiratory chain of the soil bacterium Paracoccus denitrificans and include complexes III (cytochrome $b c_{1}$ complex) and IV (cytochrome $c$ oxidase). These are well characterized multi-subunit membrane proteins, with the individual hydrophobic subunits being composed of up to 12 transmembrane helices. (J Am Soc Mass Spectrom 2007, 18, 1429-1438) (C) 2007 American Society for Mass Spectrometry
\end{abstract}

$\mathrm{B}$ iological membranes enclose and compartmentalize cells of all organisms, acting as effective insulators and selective filters between the cytoplasm and the outside medium. Being composed mainly of a double layer of phospholipids, each membrane houses a particular set of proteins or protein complexes, allowing for specific communication between the inside of a cell and its environment. Membrane proteins are centrally involved in basic cellular activities such as solute and ion transport, energy transduction in respiratory and photosynthetic systems, sensory stimuli transduction and information processing; thus they are important drug targets. Although around $20-30 \%$ of all genes are estimated to encode membrane proteins [1], our understanding for this important class of proteins lags behind for reasons of their highly hydrophobic nature, their intricate subunit structure, and their elaborate and, in many cases, only

Address reprint requests to Prof. B. Brutschy, Institute for Physical and Theoretical Chemistry, J.W. Goethe University, Max-von-Lavestr 9, 60438 Frankfurt, Germany. E-mail: brutschy@chemic.uni-frankfurt.de. transient interaction with soluble or other membranebound proteins.

Both their individual polypeptide composition and their specific assembly into larger protein complexes (i.e., their quaternary structure in the membrane) are fundamental aspects in the molecular description of their functionality. Because of their insolubility in aqueous media the analysis of membrane proteins is notoriously difficult. Physicochemical studies of membrane proteins generally require detergent treatment for solubilization, and many studies have focused on proteindetergent interactions from both functional and structural perspectives.

Since the late 1980s, mass spectrometry (MS) has increasingly been applied to the studies of proteins because of its high mass accuracy, allowing one to identify even small posttranslational modifications. The mass analysis of noncovalent protein complexes is another, still challenging goal of mass spectrometry. Presently, mainly electrospray ionization (ESI)-MS [2] and matrix-assisted laser desorption/ionization (MALDI)-MS [3], often coupled to high-performance liquid chromatography (HPLC), are used. ESI-MS has 
developed from a method to determine the molecular mass of single proteins into a tool for studying noncovalent multimeric protein assemblies ([4-6] and references cited within). In particular the ESI-MS analysis of several important soluble macromolecular complexes has been reported [7, 8]. However, the study of detergent-solubilized proteins with ESI-MS is demanding because of protein signal suppression resulting from the presence of excess detergent $[9,10]$. Thus analysis by ESI-MS usually requires the removal of detergent by organic solvents before sample analysis [11-15].

Whereas ESI-MS is now extensively used for the study of noncovalent complexes, the application of MALDI-MS in this area of research is more restricted. Nevertheless MALDI was used to analyze watersoluble proteins with molecular weights up to $300 \mathrm{kDa}$ [16] and MALDI data on the subunit stoichiometry of high mass noncovalent complexes of membrane proteins have been reported by van Dorsselaer et al. [17] and Gennis et al. [18].

Compared with these established MS methods, experiments with laser-induced liquid bead ion desorption (LILBID)-MS [19], pioneered by our group [20-23], are relatively straightforward in handling.

The biomolecules, dissolved in aqueous, buffered solution, are laser desorbed/ablated from microdroplets (average diameter $50 \mu \mathrm{m}$, volume $65 \mathrm{pL}$ ) into vacuum. For desorption the wavelength of the IR laser is tuned to the absorption maximum of water at around $3 \mu \mathrm{m}$, corresponding to an excitation of the stretching vibrations of water. At a threshold intensity of around $100 \mathrm{MW} / \mathrm{cm}^{2}$ a very fast phase transition is induced concomitant with a spherical explosion and subsequent disruption of the droplet. This results in the emission of ions from liquid into gas phase, where they can be mass analyzed by time-of-flight (TOF) spectrometry. From as low as one single droplet to, more typically, only 100 to 200 droplets are sufficient to record a mass spectrum, depending on the analyte concentration.

In the following we show that, at very low laser intensity, LILBID works in a very gentle way, which allows detection of intact membrane complexes [i.e., the complete assembly of all subunits (ultrasoft mode)]. At intermediate laser intensities (semisoft mode), complexes are partially thermolyzed into subcomplexes and subunits. Finally, at still higher intensities, the hydrophobic interactions are broken up completely and only the individual subunits are observed in the mass spectrum (harsh mode).

Thus our approach to study the membrane molecules is "top-down" and not "bottom-up," as is typical in methods used in modern proteomics.

In a proof of principle experiment, we focus on components of the respiratory chain of the soil bacterium Paracoccus denitrificans. It has been extensively studied as a model organism of the mitochondrial electron-transfer chain for its simple subunit composition, yet full functionality and its high sequence identity
[24]. Apart from other energy-converting branches, the core part of the respiratory chain system in $P$. denitrificans is highly homologous to its mitochondrial counterpart, and consists of four complexes: NADH:ubiquinone oxidoreductase (complex I); succinate:ubiquinone oxidoreductase (complex II); ubiquinol:cytochrome $c$ oxidoreductase $\left(b c_{1}\right.$ complex, complex III); and cytochrome $c$ oxidase $\left(a a_{3}\right.$ oxidase, complex IV), linked by the two-electron carrier ubiquinone and the oneelectron carrier cytochrome $c$. Here we specifically analyze complexes III and IV, as well as cytochrome $c$, which in the case of $P$. denitrificans is the membranebound cytochrome $c_{552}$. These proteins and complexes were chosen because (i) their subunit masses are known from primary sequence, (ii) they allow a wide variation in the degree of complexity in terms of subunit composition and number of transmembrane helices (TMH) present in each subunit, and (iii) the three-dimensional (3-D) structures of complex IV and of the heme domain of cytochrome $c_{552}$ have already been solved $[25,26]$.

\section{Experimental}

\section{Measurement of LILBID Spectra}

In the older version of the LILBID technique, based on continuous liquid beams, which are still applied presently [27, 28], a large consumption of analyte excluded application to the mass analysis of biomolecules of low availability. The new version, however, now uses liquid droplets [19], which minimizes the analyte consumption by orders of magnitude. The microdroplets $(\phi=50$ $\mu \mathrm{m})$ are produced on demand by a piezo-driven droplet generator and introduced by differential pumping stages into the vacuum, where they are irradiated one by one by intense nanosecond mid-IR laser pulses. The laser pulses are generated in a home-built optical parametric oscillator (OPO) based on a $\mathrm{LiNbO}_{3}$ crystal pumped by a commercial pulsed Nd-Yag laser. The moderately focused laser pulses (spot size around 300 $\mu \mathrm{m}$ in diameter, pulse duration around $6 \mathrm{~ns}$ ) are tuned to a wavelength of about $\lambda=3 \mu \mathrm{m}$, at pulse energies of 1 to $15 \mathrm{~mJ} /$ pulse, depending on the amount of desired fragmentation.

At this wavelength centered in the broad absorption band of liquid water, the laser energy is absorbed by the $\mathrm{O}-\mathrm{H}$ stretch vibrations of the water molecules within the first micrometers of the liquid surface of the droplet. At a threshold intensity of around $100 \mathrm{MW} / \mathrm{cm}^{2}$ a very fast phase transition is induced concomitant with a spherical explosion and subsequent disruption of the droplet resulting in the emission of ions from liquid into gas phase. These ions are then accelerated in a conventional pulsed two-field ion optic and mass analyzed in a home-built TOF reflectron mass spectrometer [19]. To detect very large biomolecular ions with high $\mathrm{m} / \mathrm{z}$ values we use a home-built Daly-type ion detector, working up to an $\mathrm{m} / \mathrm{z}$ range in the low megadalton region. For the present study only anions were ana- 
Table 1. Properties of three soluble $c$-type cytochromes analyzed by LILBID-MS

\begin{tabular}{lcccc}
\multicolumn{1}{c}{ Cytochrome } & $\begin{array}{c}\text { Isoelectric } \\
\text { point }\end{array}$ & $\begin{array}{c}\text { Charge at } \\
\mathrm{pH} \mathrm{7}\end{array}$ & $\begin{array}{c}\text { LILBID anion } \\
\text { charge states }^{\mathrm{b}}\end{array}$ & $\begin{array}{c}\text { Mass } \\
(\mathrm{kDa})\end{array}$ \\
\hline \hline Horse heart cyt $c$ & $10.0-10.5$ & 9.2 & 0 & 12.4 \\
Cyt $c_{1}$ CF & 4.2 & -22.2 & 4 & 23.4 \\
Cyt $c_{552}$ fragment & 5.3 & -3.7 & 1 & 12.3 \\
\hline
\end{tabular}

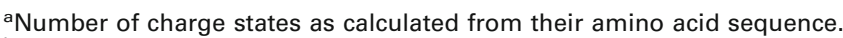

${ }^{b}$ Number of charge states as observed in LILBID-MS.

lyzed, corresponding to the net charge states of most of these proteins in solution. However, cation spectra may also be obtained, although in the case of biomolecules in general at much lower intensity.

Especially under ultrasoft desorption conditions the mass spectra often exhibit, apart from discrete ion peaks, a broad unstructured ion background, caused by metastable loss of water and buffer molecules. In those cases the broad background was subtracted from the original ion spectra. To improve the signal-to-noise ratio these difference spectra were smoothed by averaging the signal over a preset number of channels of the transient recorder, with the smoothing interval always lying within the time resolution of our TOF mass spectrometer. The spectra were mass calibrated with proteins of known mass such as lysozyme (14.3 kDa), bovine serum albumin $(67 \mathrm{kDa})$, catalase $(60 \mathrm{kDa}$ as monomer and $240 \mathrm{kDa}$ as a tetramer), and with DNA strands of different lengths, recorded under identical conditions of the apparatus.

\section{Sample Preparation}

For the initial solubilization of the membrane proteins and for all further purification steps the nonionic detergent $n$-dodecyl- $\beta$-D-maltoside (DDM; mass $=511 \mathrm{Da})$, which maintains in vitro enzymatic activity (see reference cited below) was used, if not specified otherwise. For all LILBID experiments reported here, we used ammonium acetate as standard buffer, in general at a concentration of $25 \mathrm{mM}$, and at $\mathrm{pH} 6.8$ containing $0.025 \%$ (wt/vol) of DDM. For typical measurements only $2-10 \mu \mathrm{L}$ of sample solution is required, containing the analyte in micromolar concentration. The amount of protein present in one single droplet is typically in the femto- to attomole region. Under typical conditions the recorded mass spectra are averages over 100 to 200 laser shots and droplets, respectively.

Preparation of cytochrome $c_{552}$. Heterologous expression of the His-tagged full-length cytochrome $c_{552}$ and its solubilization and purification were performed as described by Drosou et al. [29].öTheớinalð̋ufferöısedönḋhe LILBIDöexperimentsöwasöintroducedöbyöultrafiltration (Vivaspin,ö10-kDaöcutoff).

Cytochrome $b c_{1}$ complex. Theöwild-typeöP. denitrificans $b c_{1 \ddot{\circ}}$ complexöwasöpurifiedöfromäaöstrainöoverexpressing theöprotein;öcellögrowth,ömembraneöisolation,ösolubili- zation,c̈andösubsequentöproteinöpurificationöwereödone essentiallyöasödescribedöinöSchröteröetöal.ö[30],öwith modificationsödescribedönöRitteröetöal.ö[31].öForöbuffer exchange,äultrafiltrationö(Vivaspinöl00ة̈kDaöcutoff)öwas used.

Cytochrome c oxidase. Toöbtainöheöfour-subunitöpreparationö[26],ötheöproteinöwasöpurifiedöfromöwild-type membranesösolubilizedöinöDDMöasödescribedöinöHendleröetöal.ö[32].öAötwo-subunitöenzymeöcomplexöwas purifiedöinöTritonöX-100öaccordingötoöLudwigöand Schatzö[33];öinöaöfinalöpurificationöstepöthisödetergent wasöexchangedöforöDDMöbyöDEAEöanion-exchange chromatographyöfollowedöbyöultrafiltrationö(Vivaspin 100-kDaöcutoff).

Cytochrome $c_{552}$ fragment. Thisösolubleömoduleöofö100 aminoöacids,öpreparedöasödescribedöbyöReinckeöetöal.

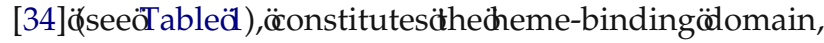
butölacksötheöN-terminalömembraneöanchor;öitsö3-D structureäsöknownö[25].

Cytochrome $c_{1}$ CF. Thisösoluble,äacidicöfragmentöofö220 aminoöacidsö(seeöTableöl)örepresentsötheöheme-binding domain and was expressed in E. coli (Janzon et al., unpublished observations).

\section{Mixture of the Three Soluble Cytochromes}

Equimolar amounts (at a concentration of $100 \mu \mathrm{M}$ each, determined spectroscopically) of three soluble cytochromes (horse heart cytochrome $c$, the $c_{552}$ fragment and the $c_{1}$ CF fragment; see above) were combined and the mixture was dialyzed extensively (4-kDa cutoff membrane) against $50 \mathrm{mM}$ ammonium acetate buffer at pH 6.8 and then diluted 10-fold for MS measurements.

\section{Chemicals}

$n$-Dodecyl- $\beta$-D-maltoside (DDM) was obtained from Merck (Darmstadt, Germany), 2-(N-morpholino)ethanesulfonic acid (MES) buffer was from AppliChem (Darmstadt, Germany), ammonium acetate (buffer grade) was from Roth (Karlsruhe, Germany), and horse heart cytochrome $c$ was from Sigma-Aldrich (Deisenhofen, Germany). All aqueous solutions were made with deionized water. 


\section{Calibration Standards}

Henöeggölysozymeöandöcatalaseöwereöpuchasedöfrom Sigma-Aldrich,öbovineöserumöalbuminöfromöBiomol (Hamburg,öGermany),öandösingle-strandedöDNAö of defineddengthöfromöBiospringö(Frankfurt,öGermany).

TheöproteinsöwereödissolvedöinöwateröandöDNA strandsönöl0ömMöammoniumöacetateäatöpHȫ.

\section{Results and Discussion}

\section{Ion Formation Mechanism and Mass Resolution}

AlthoughötheöionöformationöprocessöforöLILBIDöisöstill notöwellöcharacterized,öweöfavoröaö"luckyösurvivor" modelöforöitsörationalizationö[21].öInöthisömodelöthe photonöabsorptionänducesöaöveryöfastönonequilibrium phaseötransitionöbeyondötheösupercriticalöpoint,öfrom

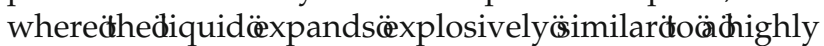
compressedögasö[19].d̈Inötheödecreasingöparticleödensity

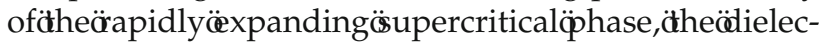
tricöconstantödropsötoözeroö[35],öandötheöno-longer-

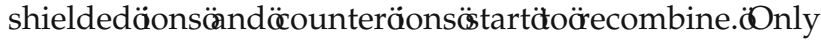
thoseöionsöescapeöintoövacuumöthatöareötooöfaröaway fromötheiröcounteröionsötoöbeötrappedöbyöCoulomb attractionđ̊[36].öAboutöneönö 0,000 öfötheösolvatedöons inđ̆hediquidähusäescapeöntoövacuum.öThusöpreformed ionsöareödetectedöasötheöresultöoföanöincompleteöion neutralizationöprocess.

Becauseöofötheösphericalöisotropicöexplosiveöexpansionö(withöaövelocityöoföaroundö800öm/s)öofötheöion cloud,ötheöpresentöresolvingöpoweröisölimitedöinöthe kilodaltonömassörangeätoäanöapproximateöM/ $\Delta$ Mövalue ofö100,öandöaövalueöevenöloweröinömassörangesöabove. Thisölimitationöinömassöresolution,öwhichöcannotöbe compensated dbyäheälelayedớieldd̈echnique,ömayäventually be overcome by collisional cooling in an ion trap and a pulsed storage depletion with subsequent orthogonal acceleration of the ions for TOF analysis, which is presently under development in our laboratory.

\section{Residual Detergent}

Any mass analysis of a complex membrane protein by MS faces two major challenges: (i) the efficient transfer of the ionic species into vacuum and (ii) a careful appraisal of the fate of the detergent molecules used to solubilize the protein. Detergents are amphipathic molecules, mimicking the native lipid bilayer environment of the isolated protein under investigation. The hydrophobic surface areas of the latter are covered by the apolar hydrocarbon chains of the detergent molecules such as dodecyl maltoside, forming either a micellar structure or a monolayer around the protein, preventingätsönonspecificäggregationönäqueousösolutionф37]. $\operatorname{DDM}(m / z=511)$ has proved to be a very useful detergent for studying a large number of membrane proteins, by providing excellent properties for solubilization and purification in monodisperse form and in preserving the enzymatic activity at the same time [38, 39$]$.

Quantitative studies showed that the number of bound detergent molecules correlates with the size of the hydrophobic surface exhibited by a complex. Typical numbers of DDM molecules bound to membrane complexes similar in size to those studied here rangeöbetweenö150öandö200ö[37].öItöshouldöbeönoted that any detergent micelle surviving the desorption process would shift the observed mass of the detected ion to considerably higher masses, easily discriminated by MS. To investigate the fate of such DDM micelles during the LILBID desorption process, we started out with the bacterial cytochrome $c_{552}$ as a simple prototypic membrane protein, consisting of only a single transmembrane helix (TMH) in its hydrophobic part.

This cytochrome shuttles electrons between the $b c_{1}$ complex and cytochrome $c$ oxidase in $P$. denitrificans. Its $\mathrm{TMH}$ is located N-terminally and is connected by a linker region to the hydrophilic C-terminus of the protein liganding the heme cofactor. For purification purposes, it was expressed heterologously with an additional hexa-His tag at its extreme N-terminus, yieldingöв̈̈alculatedömassöfö̈roundö20ةkDä̈seeöTable 2)öforötheöpolypeptide,ömakingöanyömassöshiftöarising from attached detergent molecules readily detectable within the mass resolution of our spectrometer.

Figureö1ödepictsötheömassöspectrumöoföthisösingle polypeptide. The prominent mass peaks correspond to the molecular ions $\mathbf{M}^{-}(\mathrm{m} / \mathrm{z}=19,700)$ and $\mathbf{M}^{2-}(\mathrm{m} / \mathrm{z}=$ 9900). By comparing this value to the calculated mass it is obvious that neither the whole detergent micelle nor even any single detergent molecule has survived the desorption process. Even under greatly differing desorption conditions, that is, with harsh and soft conditions applied by varying the laser intensity (see also below), no detergent contribution was observable.

Two minor, closely spaced double peaks observed in the spectrum spectrum, one pair at 14,600 and 14,800 $\mathrm{m} / \mathrm{z}$ and another at 5000 and $5200 \mathrm{~m} / \mathrm{z}$, are neither fragment ions produced by the laser desorption process, nor any impurities, but represent proteolysis products generated at nearby sites of the polar part of the protein, which were not separated in the chromatographic preparation of the sample before mass analysis. This assignment is supported by the fact that the two ion masses add up to the expected full-size protein mass. In addition, the larger species corresponds to a fragment recognized by specific anti-cytochrome $c_{552}$ antibodies in a Western blot analysis (not shown).

Next we addressed the question of whether the complete loss of all detergent molecules similarly holds true for membrane proteins exhibiting a more complex topology of TMHs, characterized by grooves between adjacent TMHs, that may favor a stronger binding of detergent molecules. 
Table 2. Subunit composition and masses of the detected ions of selected respiratory membrane protein complexes

\begin{tabular}{|c|c|c|c|c|c|c|c|c|c|}
\hline Protein & $\begin{array}{c}\text { Subunit } \\
\text { (SU) }\end{array}$ & $\begin{array}{c}\text { Number of } \\
\text { TMHs }\end{array}$ & $\begin{array}{c}\text { Number } \\
\text { of AAs }\end{array}$ & $\begin{array}{l}\text { Isoelectric } \\
\text { point }\end{array}$ & $\begin{array}{c}\text { Charge at } \\
\mathrm{pH} 7^{\mathrm{a}}\end{array}$ & $\begin{array}{l}\text { LILBID anion } \\
\text { charge } \\
\text { states }^{\mathrm{b}}\end{array}$ & $\begin{array}{c}\text { Apparent } \\
\text { mass } \\
(\mathrm{kDa})^{\mathrm{c}}\end{array}$ & $\begin{array}{l}\text { Mass } \\
(k D a)^{d}\end{array}$ & $\begin{array}{l}\text { LILBID } \\
\text { mass } \\
(\mathrm{kDa})^{\mathrm{e}}\end{array}$ \\
\hline Cytochrome $C_{552}$ & & 1 & 184 & 5.5 & -9.0 & 2 & 26 & 19.9 & 19.7 \\
\hline Complex III & ISP & 1 & 190 & 4.3 & -9.5 & 1 & 20 & 20.4 & 20.1 \\
\hline Complex III & cyt $c_{1}$ & 1 & 426 & 3.8 & -76.0 & 3 & 60 & 45.3 & 45.0 \\
\hline Complex III & cyt $b$ & 8 & 440 & 6.2 & -4.7 & 1 & 40 & 51.4 & 49.6 \\
\hline Complex IV & SUI & 12 & 558 & 6.4 & -4.4 & 2 & 45 & 64.1 & 62.3 \\
\hline Complex IV & SU II & 2 & 252 & 4.6 & -11.6 & 2 & 28 & 28.1 & 27.9 \\
\hline Complex IV & SU III & 7 & 273 & 6.0 & -5.0 & 2 & 23 & 30.6 & 30.6 \\
\hline Complex IV & SU IV & 1 & 49 & 6.6 & -0.5 & 1 & 5 & 5.4 & 5.4 \\
\hline
\end{tabular}

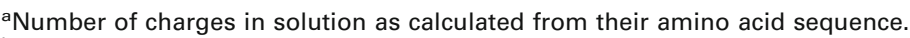

${ }^{b}$ Number of charge states as observed in LILBID-MS.

${ }^{c}$ Apparent molecular mass deduced from SDS-PAGE (for details, see reference cited in the text).

${ }^{\mathrm{d}}$ Deduced from sequence.

eMolecular mass derived from LILBID-MS.

\section{Complex IV: Cytochrome c Oxidase}

Cytochrome $c$ oxidase, also termed complex IV, is a structurally far more elaborate membrane protein. It oxidizes cytochrome $c_{552}$ and transfers electrons to the terminal acceptor of the respiratory chain, dioxygen, with the free energy of this reaction coupled to transmembraneöprotonötranslocationö[40,ö41].öTheöstructure of complex IV from $P$. denitrificans is known with high resolutionö[26].öThisöenzymeöisöcomposedöoföfouröhydrophobicösubunitsö̈ädifferentöomplexitiesäseeöTable 2öforödetails).öSubunitölöconsistsöoföl2ötransmembrane helices and is almost completely buried in the membrane with only short connecting loops. It carries three redox centers (two hemes $a$ and the copper B center [26]).öSubunitöIIöhasöaösplitöarchitectureöwithötheötwo membrane-spanning $\alpha$-helices in its $\mathrm{N}$-terminal domain and a 10-stranded $\beta$-barrel hydrophilic domain at the C-terminus, which houses the $\mathrm{Cu}_{\mathrm{A}}$ center. The seven helices of subunit III are highly hydrophobic and com-

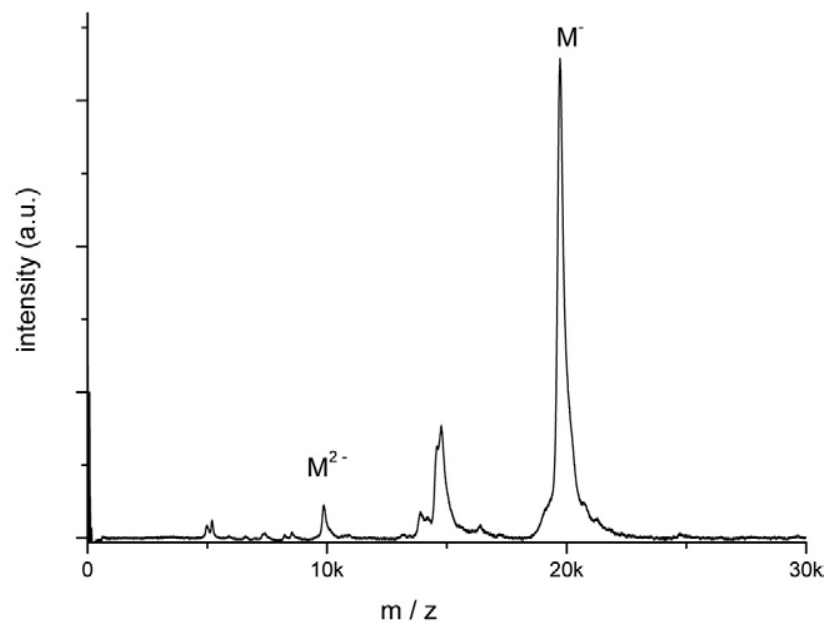

Figure 1. LILBID mass spectrum of cytochrome $c_{552}$. The molecule peak $(\mathrm{M})$ is observed singly and doubly charged. At 5000 and $5200 \mathrm{~m} / \mathrm{z}$ and at 14,600 and $14,800 \mathrm{~m} / \mathrm{z}$ two proteolytic fragments not separated by the previous purification steps are visible (see text). pletely embedded in the membrane, lacking any redox centers, whereas subunit IV consists of essentially a singleöTMHö[42].öAöfunctionallyöactiveöversionöoföthis complex may also be isolated that lacks subunits III and IV̈̈[33].

A mass spectrum of the solubilized complex IV, taken under very mild desorption conditions, is given inöFigureä2a.öTheöxidaseäomplexäpppearsäsäöregular sequence of broad mass peaks, corresponding to different charge states of the complex, ranging from one to five negative charges. Because the mass of the detected complex is $>126 \mathrm{kDa}$ (see below), apparently no major fragmentation into individual subunits occurs under these conditions.

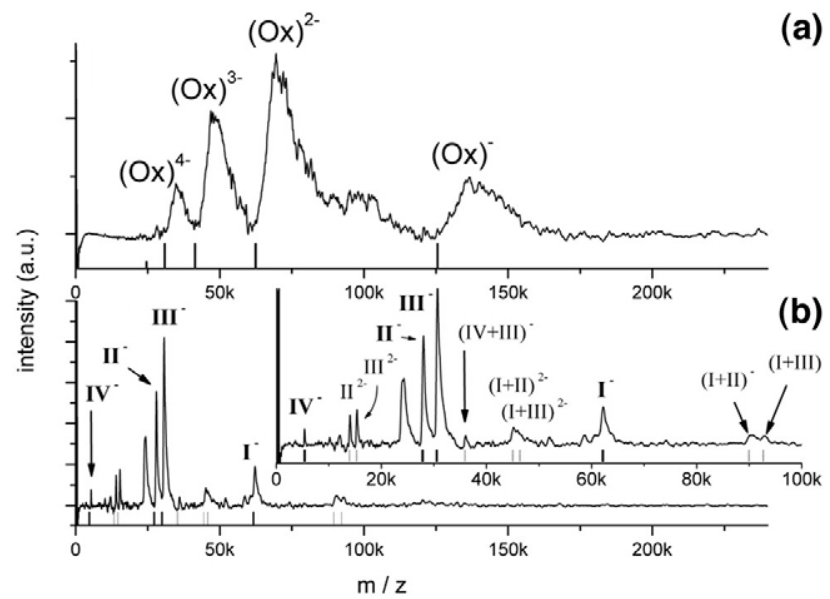

Figure 2. Mass spectra of the four-subunit cytochrome $c$ oxidase complex. (a) The anion spectrum taken under ultrasoft desorption conditions. The intact oxidase complex is visible; the black stick spectrum below the experimental trace indicates the theoretical mass/charge ratio for oxidase ions with charges between 1 and 4 . The band broadening is attributed to residual detergent molecules and/or water still adhering to the complex (see text). (b) The same spectrum measured under harsh desorption conditions. The theoretical positions of the four subunits are indicated by a stick spectrum (black). Further ion signals are assigned to subcomplexes and doubly charged molecules (gray lines; see text). A peak at $24,000 \mathrm{~m} / \mathrm{z}$ could not be accounted for. 
It should be noted that the center of the mass peaks is shifted to $\mathrm{m} / \mathrm{z}$ values larger than the theoretical ones of oxidase, indicated at the bottom of the trace by a stick spectrum. In addition, the shape of the mass peaks is not quite symmetric, with a rising edge a little steeper compared to the more slowly falling edge trailing to higher masses. Because such broad peaks are observed only under ultrasoft desorption conditions, this peak shape may be rationalized mostly by residual detergent molecules still attached to the molecular ion of the complex. We cannot exclude the possibility that residual phospholipids and water molecules adhere as well.

This contrasts with the situation of a protein carrying only a single TMH such as the cytochrome $c_{552}$ discussed earlier, where the surrounding micelle did not survive the ion desorption process. With proteins of more complex transmembrane secondary structure such as oxidase, however, some of the detergent molecules together with water molecules obviously remain attached, broadening and shifting the mass peaks toward higher $\mathrm{m} / \mathrm{z}$ values. It appears plausible that detergent molecules buried in the grooves between helices, especially, are bound more firmly and therefore survive the ionization process. The onset of the mass peaks is located at the theoretical values. If one assumes that the peak broadening is preferentially caused by residual detergent molecules, the position of the peak maxima (corresponding to a molecular weight of $132 \mathrm{kDa}$ with $z$ $=1$ to 4 ) suggests that an average of 20 to 25 molecules of DDM survive the desorption. According to the estimated number of initially bound detergent molecules (see above), this would correspond to about $10-15 \%$ of the initial detergent molecules that remain attached to the protein complex. Considering the distribution of the oxidase signals corresponding to a molecular weight of $126 \mathrm{kDa}(z=1$ to 4$)$ plus detergents, it is obvious that the four-subunit oxidase is present as a monomer under the conditions of the present study, whichöconfirmsöearlieröfindingsä[43,ö44].

To disintegrate the complex into its subunits for analyzing their mass, the intensity of the desorption laser has to be increased stepwise. With additional energy transferred into the complex by elevated laser power, noncovalent interactions between the subunits are broken up, releasing the four oxidase subunits for MS analysis as separateömacromolecules.öFigureö2bödepictsötheömass spectrum under such conditions, where all four subunits (I-IV) are observed singly charged. However, subunits II and III show higher intensities and also appear as doubly charged ions. These differences between subunits with identical stoichiometry in the complex may be rationalized by the higher net charge of subunits II and III at neutral $\mathrm{pH}$ in solution. The response function of the LILBID process obviously favors the detection of ions according to their net charge state in solution, as will be discussed more thoroughly in the context of the findings for $b c_{1}$ complex.

In addition ion signals of minor intensity can be observed in the spectrum, as can be seen more clearly in

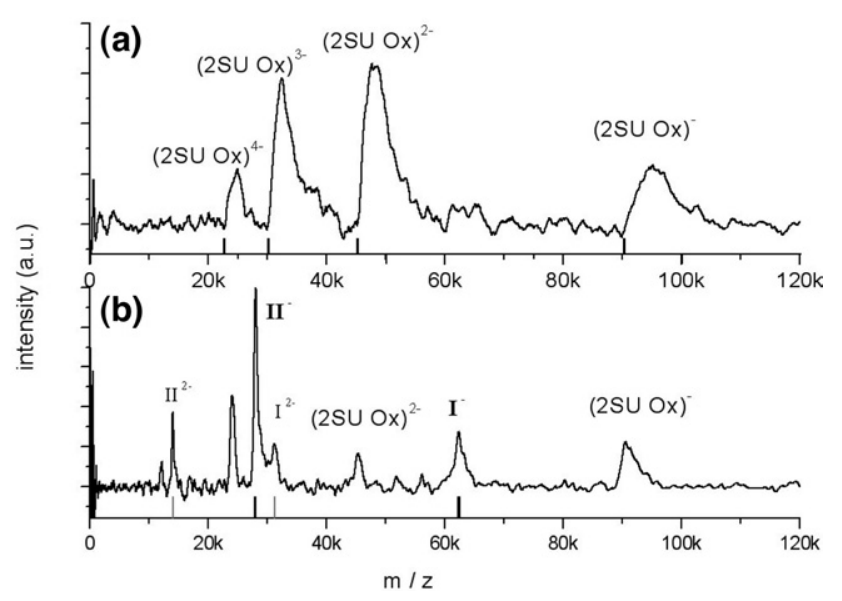

Figure 3. Mass spectrum of the two-subunit (2SU) cytochrome $c$ oxidase. (a) under ultrasoft desorption conditions: The intact complex appears at four different charge states (black stick spectrum indicates the theoretical mass/charge positions) (b) measured with higher laser power. The intensity of the intact complex decreases and ion signals of the individual subunits show up (indicated by black stick spectrum; doubly charged ions indicated by gray stick spectrum). The subunit ions lack any additional detergent molecules and the remaining complex peaks reveal that the residual detergents have been further diminished. The peak at $24,000 \mathrm{~m} / \mathrm{z}$ remains unexplained; if it represents an impurity from the purification procedure, it is not resolved in the standard SDS gel control.

theöenlargedöpartöoföFigureö2b.öTheyöareöassignableöto subcomplexes composed of heterodimers of subunits such as I + II, I + III, and III + IV. It should be pointed out that no dimers II + III, II + IV, or homodimers are observed. The detectable subcomplexes consist of adjacent subunits and obviously arise from an incomplete fragmentation of the native complex. Thus the intensity and composition of these subcomplexes reflect the next-neighbor relationships of subunits, optimized for their contact areas and thus for stronger hydrophobic interactions in the complex. These conclusions are in very good agreement with the structure of the oxidase complexöasödeterminedöbyöX-rayödiffractionö[26].öThus random aggregation of subunits by gas-phase reactions can clearly be excluded.

A modified cytochrome $c$ oxidase complex containing only subunits I and II was also investigated for comparison. This fully functional oxidase complex results from a purification procedure using Triton X-100 ([33]; ̈̈̈ndöseeëabove), ëffectivelyöremovingösubunitsöIII and IV. Under the most gentle desorption conditions this complex appears as several charge states, ranging

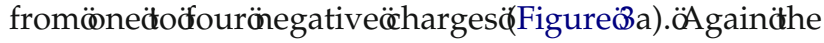
mass peaks of the complex are substantially broadened and shifted to higher masses, mainly as the result of residual detergent and possibly water molecules. For the two-subunit oxidase it has been shown that all phospholipids are removed by this stringent purificationöprocessö[33].öSoötheömaximumöofötheödetergentbased peak broadening corresponds to 10-12 residual DDM molecules, indicating a relative loss of detergent 
moleculesö(basedöonötheönumberöoförespectiveöTHMs) comparableätoöhhatöofötheöfour-subunitöoxidase.

Uponöncreasingötheölaseröpower,ötheöionösignalsöof theö intactö complexödecreaseö andö thoseö ofö theö two individualösubunitsđ̄öandđ̈Iödominateähëspectrum,äs shownänđ̈Figureößb.đnderđ̈hesedharsheröonditionsöno majorö contributionsö ofödetergentömoleculesöareöobservedöforöheösubunitöons,äandöforöheöreducedösignal ofötheöintactöcomplexöaöstronglyödiminishedöresidual detergent contribution is seen.

\section{Complex III: Cytochrome $b c_{1}$ Complex}

Another multisubunit membrane protein of the bacterial respiratory chain, which we analyzed by LILBID-MS is the cytochrome $b c_{1}$ complex, also known as complex III. The structure of this protein isolated from different mitochondrial sources such as yeast is known fromöX-rayödiffractionä(e.g., ¿45]).̈̈Complexđ̈Iİ̈ransfers electrons from ubiquinol to cytochrome $c$. During this reaction protons are translocated across the membrane by the Q-cycle, contributing to the generation of the proton gradient. The bacterial complex analyzed here consists of three subunits: (i) the Rieske iron-sulfur protein (ISP), which has an N-terminal TMH and an extensive C-terminal hydrophilic domain connected through a flexible linker region; (ii) the cytochrome $b$, whichösdhighlyd̈hydrophobicöseeöTableà) ẅwithötsäight TMHs almost completely buried in the membrane, binding the two $b$ heme cofactors noncovalently; and (iii) cytochrome $c_{1}$ with a C-terminal transmembrane

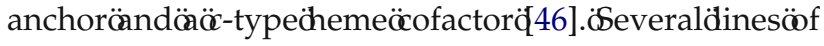
evidence indicate at least a dimeric structure both for the mitochondrial and the bacterial complex III. Crystal structuresöforöbothötypesö(e.g.,ö[45,ö47,ö48])öshowöa mutually intertwined organization for the ISP subunit, being embedded in one monomer by its $\mathrm{N}$-terminal anchor, while serving the other monomer in a mechanism described as a major movement of the FeS cofactor domainö duringö intracomplexö electronö transferö [49]. Dimericö[44]öandöevenöhigheröoligomericöstructures have been observed by other techniques as well, such as gelơfiltrationöandöblueönativeöPAGË̈[50].

Under "gentle" desorption conditions, the intact complexäsädetectedöhereäsöwell.öAsädepictedönđ̈Figure 4a,ötheömassöspectrumöshowsöaöseriesöoföpeaksöthat clearly correspond to a charge distribution of the $b c_{1}$ complex, oligomerized to a tetramer. To distinguish between the ion distribution of a multiply charged dimer and tetramer, the corresponding stick spectra are includedöschematicallyänöFigureöłböandö.öTheöexperimental spectrum gives no indication for the presence of a dimer, nor any other unspecific oligomeric forms. This indicates that the tetramer is probably the native quaternary structure of the complex in solution as well as in a supercomplex stoichiometry. Referring to the intertwined structure of the two monomers, it should rather be regarded as a pair of dimers. Again the mass peaks of the integral complex are considerably broadened as a

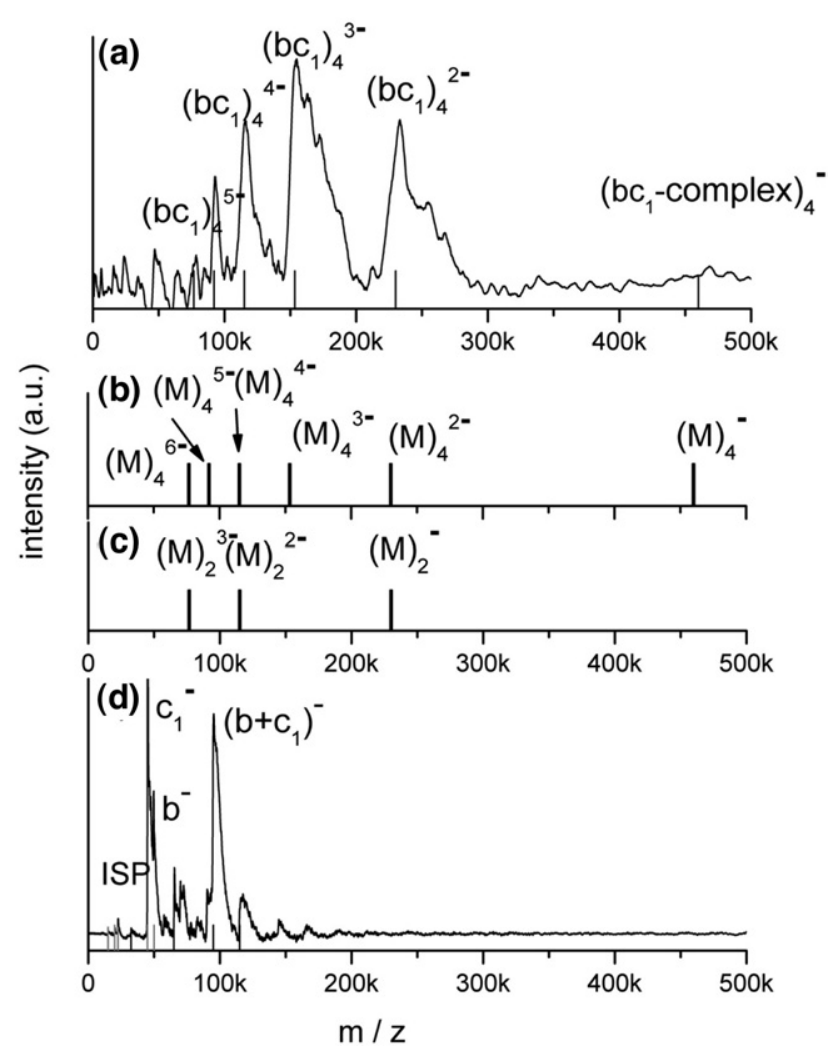

Figure 4. Mass spectrum of the cytochrome $b c_{1}$ complex. (a) At low laser intensity the $b c_{1}$ complex is detected as a tetramer, as deduced by comparison with the theoretical charge distributions for the $b c_{1}$-complex, calculated in (b) for a tetramer and (c) for a dimer. (d) Upon increase of the laser intensity the complex desintegrates into subcomplexes and the individual subunits. FurtherödetailsöareödepictedönöFigureöb.

result of residual detergent and/or water molecules surviving the desorption process. However, it should be pointed out that the overall detergent-induced broadening of the mass peaks of the $b c_{1}$ complex differs from that of cytochrome $c$ oxidase.

For the $b c_{1}$ complex the peak maxima correspond to the theoretical mass/charge values of the tetrameric $b c_{1}$ complex with only very few residual detergent molecules attached, and a detergent distribution directly trailing off toward larger numbers of residual detergents. The peak shapes for the oxidase ions on the other handöareödifferentö(seeöFigureö2a), öwithötheiröobserved maxima shifted by a mass increase corresponding to 20 to 25 additional DDM molecules.

A possible explanation for the different numbers of residual detergent molecules in case of the four-/twosubunit oxidase and the tetrameric $b c_{1}$ complex, respectively, may be found in a different ruggedness of the hydrophobic landscape, leading to a different affinity for binding and, thus, for retaining detergent molecules resulting from the laser desorption.

Figureö4döshowsöaöspectrumöofötheösameösample when analyzed at elevated laser intensity $(20 \mathrm{~mJ} /$ pulse). The intact tetrameric complex is no longer visible because of the enhanced thermal energy input 
intoähediquidödroplets.öConsequently,öonlyändividual subcomplexesöandösubunitsöappearöinötheölowerömass regionöoföheöspectrum.

Becauseötheöinteractionöbetweenötheöcytochromeöb andötheöcytochromeö $c_{1}$ subunitsöisöstrongeröthanöthat betweenötheöcytochromeö $c_{1}$ andötheöRieskeö protein (mainlyöembeddedöinötheöotherömonomer;öseeöabove), theö $\left(b+c_{1}\right)$ s̈ubcomplexesösurviveöwithöhigheröproba-

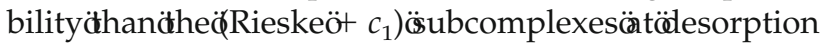
conditions,öwhichäreälreadyđ̈oođharshơforđheäntegral tetramerätoöwithstand.öTherefore,ösimilarötoötheöcaseöof oxidase,önext-neighborörelationshipsöoföproteinsöinöthe complexärreöqualitativelyöreflectedönötheömassöspectra (Figureö5a).öUponöfurtheröincreaseöofötheölaseröpower (Figureȫb)ötheseöbinaryösubcomplexesöareödissociated asöwell.

Althoughöcytochromeöb andötheöRieskeösubunitöare observedöinötheöspectrumöonlyöasösinglyöchargedöspecies,äheöonösignalöofäheöcytochrome $\ddot{c}_{10 ̈}$ polypeptideäs veryäntenseöandönöadditionöappearsönöhigheröcharge states.öTheseödifferentäonöntensitiesönndöchargeöstates

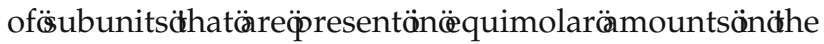
complex,öcorrelateänösomeöwayöwithöheönetöchargeöof theäonsönösolution,ëssëalculated đ̛romäheiräminoäcid sequenceö(seeöTableö2).öTheömostäntenseömassöpeakän

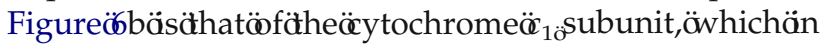
additionösöpresentänähreeödifferentöhhargeöstates.öThe

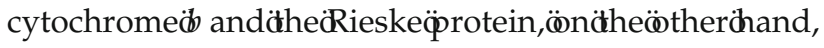
carryöonlyöä̈singleöhargeändöbothöappearöatöstrongly reduced intensities in the LILBID mass spectrum. A clear correlation between the charge state in solution and in the gas phase is evident.

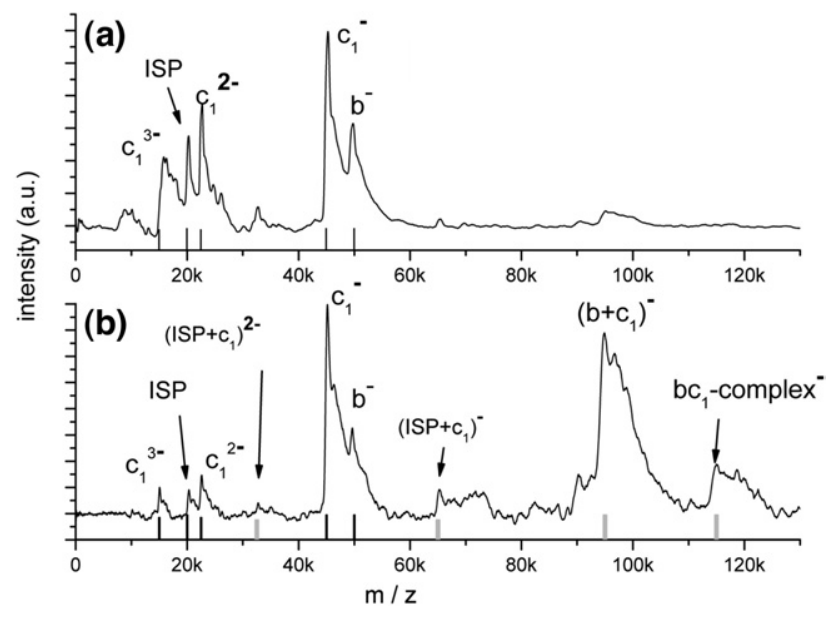

Figure 5. Mass spectra of the cytochrome $b c_{1}$ complex at elevated laser intensity (a) at very harsh desorption conditions only the subunits survive (indicated by black sticks), (b) at more gentle conditions also subcomplexes (gray sticks) of the subunits appear, yielding information on their binding contacts with adjacent subunits in the complex.

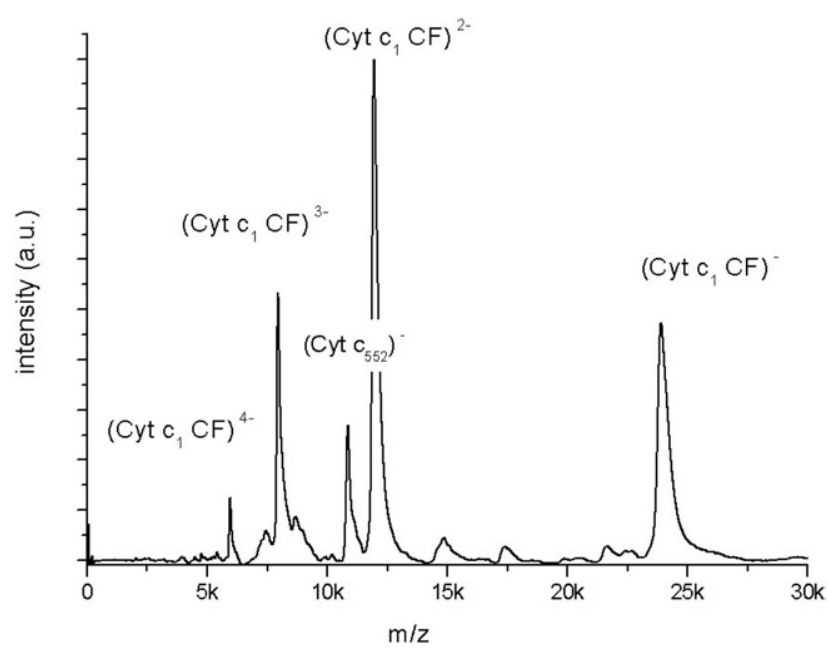

Figure 6. Mass spectrum of an equimolar mixture of three different soluble cytochromes $c$, differing in their isoelectric points. Cytochrome $c_{1} \mathrm{CF}$ with the lowest IP shows the most intense signals and a charge distribution from 1 to 4 . The cytochrome $c_{552}$ fragment, with an intermediate isoelectric point, is less intense and appears only singly charged, whereas horse heart cytochrome $c$ with its strong positive net charge cannot be seen.

\section{Charge Distribution of the Proteins in Gas Phase in View of Their Isoelectric Point}

To further verify this correlation between the charge state of proteins in solution and their ion signal in the mass spectrum three different soluble cytochromes $c$ were investigated, chosen both for their different isoelectricöpointsö(seeöTableöl)öandöthereforeödifferentönet chargesöatöneutralöpHö(Figureö6),,öandöforötheirösimple spectroscopic quantitation by their heme groups. MS spectra were recorded at neutral $\mathrm{pH}$ in the standard buffer (omitting the detergent) at equimolar concentration for each of the cytochromes.

As expected, cytochrome $c_{1} \mathrm{CF}$ (isoelectric point: 4.2) yields the most intensive peaks with a negative charge distribution from 1 to 4 . Less intense is the signal of cytochrome $c_{552}$, which appears only singly charged. The horse heart cytochrome $c$ with an isoelectric point $>10$ is not visible in the anion spectrum at all. In the combined cytochrome solution MS assay it might be difficult to resolve because its mass is close to the doubly charged cytochrome $c_{1} \mathrm{CF}$, although measurements of horse heart cytochrome $c$ alone confirmed the negative result (not shown).

These data support the "lucky survivor" mechanism suggested for LILBID: Because it postulates an incomplete ion neutralization in the explosive expansion of the preformed ions, one expects the molecules with higher charge state in aqueous solution to have a larger neutralizationescape probability than the less charged species, purely for statistical reasons. So a higher endogenous charge on a polypeptide results in a larger ion recovery and a distribution of higher charge states of the ion peaks.

By these arguments different charge distributions of the ions in a LILBID measurements qualitatively reflect 
theönetähargeöpresentönösolutionösölerivedöromäheir aminoöacidösequenceö(Tableö2).

Fromötheöpresentöstillöscarceödataöitöisötooöearlyöto discussötheöchargeöstateöquestionöquantitativelyöandön greaterödepth.öWhatöweöreportöhereöareötrends,öwhich areödifferentlyöpronouncedöforötheödifferentöproteins. Thisömayd̈bedbecauseäonörecombinationöshouldälsodbe dependentönötheösiteöfötheöcharge, ähed̈ocalödielectric constant,öionöstrength,öandösoöforth.öAtöleastötheöcom-

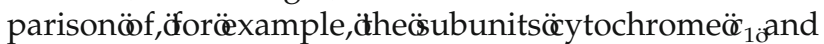
cytochromeäb fromäomplexđ̈IIä(Figureळ̄), öwhichäreöf similarömassöbutöwithöveryödifferentöchargeöstateöand peaköintensity,öclearlyöshowsöthatötheöaverageöcharge perömassöisönotöcomparable.öThisöspeaksöagainstöa mass/size-dependentöstatisticalöchargeödistribution.

Alongöthisölineöoföargumentöclearly,öbecauseöoföthe charge-dependentöLILBIDöresponseöfunctionöforöproteins, đ̇heörelativeöpeaköntensitiesönđ̆dheömassöspectrum cannotdeeässedđ̇oäletermineäntrinsicöstoichiometriesöf subunitsönöaögivenöcomplexöoränöaöproteinömixture.

\section{Conclusions}

LILBID-MSöisöaöveryöpromisingömethodöforötheösoft massöanalysisöofömembraneöproteinsöbecauseöitöallows theḋransferø̈fdargeönacromolecularø̈omplexesöntoḋhe gasöphaseöföheömassöspectrometer. Simplydbyörarying theölevelöofölaseröintensityöinötheödesorptionöprocess, differentöstagesöfödisintegrationöfötheömembraneöpro-

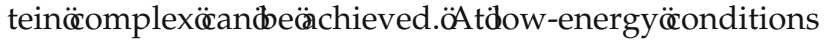
evenöveryd̈argeöntegralöcomplexesöreätransferredönto vacuumöandömayöbeöletectedöunfragmented, örevealing theiröoligomericöassociationöstate.öDependingöonöthe complexityöofötheöhydrophobicöpartöofötheöproteinsöup toö $5 \%$ öfö̀heöletergentömoleculesöremainöboundötoähe macromoleculeöunderötheseöultrasoftöconditions.öAt elevatedälaseröntensity, ̈however,ötheseöresidualödetergentömoleculesöareöstrippedöofföconcomitantöwithöthe

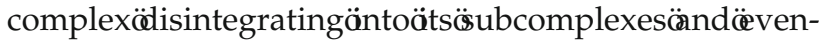

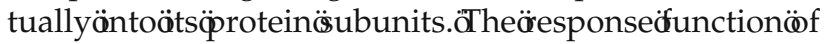
thisömassösectrometryớavorsäheäletectionø̈fäheömore highlyöchargedöproteinsöinösolution,öandötheiröappearanceöatöhigheröchargedöstatesöinötheögas-phaseöLILBID massöspectrum,öthusöreflectingötendenciesöofösolution behavior.

Becauseötöequiresönlyöreryömallöampleäquantities (inötheöpicomoleörange)öwithösolutionövolumesöinöthe microliteröangedLILBID-MSöpensönew ̈̈venuesớord̆he massöspectrometryöoföcomplexömembraneöproteins.ölts relativeätoleranceätowardödetergentsösöä̈rucialößvantageöverötherơMSömethods.đ̈täsäsösoftäsöänondenaturatingögelöbutöhasöatöleastöoneöorderöofömagnitude higherömassöaccuracyöcomparedötoöthatö oföelectrophoreticöanalysis,ö whereö theö determinedö massesö of

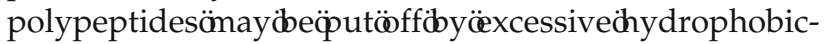
ityöoröcharge.öMoreover,ötheömassöanalysisöoföeven highlyöhydrophobicösubunits,öwhichöareödifficultöto analyzeöbyöconventionalöMSömethods,äsëeasilyöamenableöbyöuseöoföthisötechnique.öFurtheröadvantagesöin comparisonḋö̈nalyticaläıltracentrifugationđ[51]äreḋhe

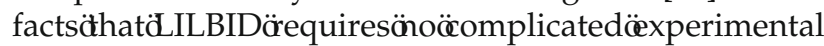
determinationöofötheöamountöoföboundödetergentöand needsöonlyöveryösmallöamountsöoföanalyte.öTheöstill modestömassöresolution, öobtainedöwithöouröhome-built TOF, can readily be improved by coupling the LILBID ion source to a high-resolution mass spectrometer. For a future setup the additional option to sequence the subunit proteins by multidimensional $\mathrm{MS}\left(\mathrm{MS}^{n}\right)$ is currently being developed.

\section{Acknowledgments}

The authors thank Werner Müller for excellent technical assistance and Julia Janzon for providing the cytochrome $c_{1}$ fragment. The authors also acknowledge financial support from Collaborative Research Centers Grants SFB 472 and 579.

\section{References}

1. Heijne, G. v. Membrane-Protein Topology. Nat. Rev. Mol. Cell. Biol. 2006, 7, 909-918.

2. Fenn, J. B.; Mann, M.; Meng, C. K.; Wong, S. F.; Whitehouse, C. M. Electrospray Ionization for Mass Spectrometry of Large Biomolecules. Science 1989, 246, 64-71.

3. Tanaka, K.; Waki, H.; Ido, Y.; Akita, S.; Yoshida, Y.; Yoshida, T. Protein and Polymer Analyses up to $m / z 100000$ by Laser Ionization Time-ofFlight Mass Spectrometry. Rapid Commun. Mass Spectrom. 1988, 2, 151-153.

4. Sobott, F.; Robinson, C. V. Protein Complexes Gain Momentum. Curr. Opin. Struct. Biol. 2002, 12, 729-734.

5. Miranker, A. D. Protein Complexes and Analysis of Their Assembly by Mass Spectrometry. Curr. Opin. Struct. Biol. 2000, 10, 601-606.

6. Loo, J. A. Studying Noncovalent Protein Complexes by Electrospray Ionization Mass Spectrometry. Mass Spectrom. Rev. 1997, 16, 1-23.

7. Rostom, A. A.; Fucini, P.; Benjamin, D. R.; Juenemann, R.; Nierhaus, K. H.; Hartl, F. U.; Dobson, C. M.; Robinson, C. V. Detection and Selective Dissociation of Intact Ribosomes in a Mass Spectrometer. Proc. Natl. Acad. Sci. U.S.A. 2000, 97, 5185-5190.

8. Fitzgerald, M. C.; Chernushevich, I.; Standing, K. G.; Whitman, C. P. Kent, S. B. Probing the Oligomeric Structure of an Enzyme by Electrospray Ionization Time-of-Flight Mass Spectrometry. Proc. Natl. Acad. Sci. U.S.A. 1996, 93, 6851-6856.

9. Loo, R. R. O.; Dales, N.; Andrews, P. C. Surfactant Effects on Protein -Structure Examined by Electrospray-Ionization Mass-Spectrometry. Protein Sci. 1994, 3, 1975.

10. Rundlett, K. L.; Armstrong, D. W. Mechanism of Signal Suppression by an Ionic Surfactant in Capillary Electrophoresis Electrospray Ionization Mass Spectrometry. Anal. Chem. 1996, 68, 3493-3497.

11. Whitelegge, J. P.; Gomez, S. M.; Faull, K. F. Proteomics of Membrane Proteins. Adv. Protein Chem. 2003, 65, 271-307.

12. Whitelegge, J. P. Tandem Mass Spectrometry of Integral Membrane Proteins for Top-down Proteomics. TrAC, Trends Anal. Chem. 2005, 24, 576-582.

13. Whitelegge, J. P.; Le Coutre, J.; Lee, J. C.; Engel, C. K.; Privè, G. G.; Faull, K. F.; Kaback, H. R. Toward the Bilayer Proteome, Electrospray Ionization-Mass Spectrometry of Large, Intact Transmembrane Proteins. Proc. Natl. Acad. Sci. U.S.A. 1999, 96, 10695-10698.

14. Hufnagel, P.; Schweiger, U.; Eckerskorn, C.; Oesterhelt, D. Electrospray Ionization Mass Spectrometry of Genetically and Chemically Modified Bacteriorhodopsins. Anal. Biochem. 1996, 243, 46-54.

15. Caroll, J.; Fearnley, I. M.; Walker, J. E. Definition of the Mitochondrial Proteome by Measurements of Molecular Masses of Membrane Proteins. Proc. Natl. Acad. Sci. U.S.A. 2006, 103, 16170-16175.

16. Cohen, S. L.; Chait, B. T. Mass Spectrometry of Whole Proteins Eluted from Sodium Dodecyl Sulfate-Polyacrylamide Gel Electrophoresis Gels. Anal. Biochem. 1997, 247, 257-267.

17. Schindler, P. A.; Van Dorsselaer, A.; Falick, A. M. Analysis of Hydrophobic Proteins and Peptides by Electrospray Ionization Mass Spectrometry. Anal. Biochem. 1993, 213, 256-263.

18. Ghaim, J. B.; Tsatsos, P. H.; Katsonouri, A.; Mitchell, D. M.; SalcedoHernandez, R.; Gennis, R. B. Matrix-Assisted Laser Desorption Ionization Mass Spectrometry of Membrane Proteins: Demonstration of a Simple Method to Determine Subunit Molecular Weights of Hydrophobic Subunits. Biochim. Biophys. Acta 1997, 1330, 113-120.

19. Morgner, N.; Barth, H.-D.; Brutschy, B. A New Way to Detect Noncovalently Bonded Complexes of Biomolecules from Liquid Micro-Droplets by Laser Mass Spectrometry. Aust. J. Chem. 2006, 59, 109-114.

20. Sobott, F.; Schunk, S. A.; Schüth, F.; Brutschy, B. Examination of Condensation Products of Group 4 Alkoxides with Laser-Induced 
Liquid Beam Ionization/Desorption Mass Spectrometry. Chem. Eur. J. $1998,4,2353-2359$.

21. Kleinekofort, W.; Avdiev, J.; Brutschy, B. A New Method of Laser Desorption Mass Spectrometry for the Study of Biological Macromolecules. Int. J. Mass Spectrom. Ion Processes 1996, 152, 135-142.

22. Kleinekofort, W.; Pfenninger, A.; Plomer, T.; Griesinger, C.; Brutschy, B. Observation of Noncovalent Complexes Using Laser-induced Liquid Beam Ionization/Desorption. Int. J. Mass Spectrom. Ion Processes 1996, 156, 195-202.

23. Kleinekofort, W.; Schweitzer, M.; Engels, J.; Brutschy, B. Analysis of Double-stranded Oligonucleotides by Laser-induced Liquid Beam Mass Spectrometry. Int. J. Mass Spectrom. Ion Processes 1997, 163, L1-L4.

24. Baker, S. C.; Ferguson, S. J.; Ludwig, B.; Page, M. D.; Richter, O.-M. H.; van Spanning, R. J. M. Molecular Genetics of the Genus ParacoccusMetabolically Versatile Bacteria with Bioenergetic Flexibility. Microbiol. Mol. Biol. Rev. 1998, 62, 1046-1078.

25. Harrenga, A.; Reincke, B.; Rüterjans, H.; Ludwig, B.; Michel, H. Structure of the Soluble Domain of Cytochrome $C_{552}$ from Paracoccus denitrificans in the Oxidized and Reduced States. J. Mol. Biol. 2000, 295, 667-678.

26. Iwata, S.; Ostermeier, C.; Ludwig, B.; Michel, H. Structure at $2.8 \AA$ Resolution of Cytochrome $c$ Oxidase from Paracoccus denitrificans. Nature 1995, 376, 660-669.

27. Charvat, A.; Bogehold, A.; Abel, B. Time-resolved Micro Liquid Desorption Mass Spectrometry: Mechanism, Features, and Kinetic Applications. Aust. J. Chem. 2006, 59, 81-103.

28. Kohno, J. Y.; Toyama, N.; Buntine, M. A.; Mafune, F.; Kondow, T. Gas Phase Ion Formation from a Liquid Beam of Arginine in Aqueous Solution by IR Multiphoton Excitation. Chem. Phys. Lett. 2006, 420, 18-23.

29. Drosou, V.; Reincke, B.; Schneider, M.; Ludwig, B. Specificity of Interaction between the Paracoccus denitrificans Oxidase and Its Substrate Cytochrome $c$ : Comparing the Mitochondrial to the Homologous Bacterial Cytochrome $c_{552}$, and Its Truncated and Site-directed Mutants. Biochemistry 2002, 41, 10629-10634.

30. Schröter, T.; Hatzfeld, O. M.; Gemeinhardt, S.; Korn, M.; Friedrich, T.; Ludwig, B.; Link, T. A. Mutational Analysis of Residues Forming Hydrogen Bonds in the Rieske [2Fe2S] Cluster of the Cytochrome $b c_{1}$ Complex in Paracoccus denitrificans. Eur. J. Biochem. 1998, 255, 100-106.

31. Ritter, M.; Anderka, O.; Ludwig, B.; Mäntele, W.; Hellwig, P. Electrochemical and FTIR Spectroscopic Characterization of the $b c_{1}$ Complex from Paracoccus denitrificans: Evidence for Protonation Reactions Coupled with Quinone Binding. Biochemistry 2003, 42, 12391-12399.

32. Hendler, R. W.; Pardhasaradhi, K.; Reynafarje, B.; Ludwig, B. Comparison of Energy-transducing Capabilities of the Two- and Three-Subunit Cytochromes $a a_{3}$ from Paracoccus denitrificans and the 13-Subunit Beef Heart Enzyme. Biophys. J. 1991, 60, 415-423.

33. Ludwig, B.; Schatz, G. A Two-Subunit Cytochrome mdit $>$ c Oxidase (Cytochrome $a a_{3}$ ) from Paracoccus denitrificans. Proc. Natl. Acad. Sci. U.S.A. 1980, 77, 196-200.

34. Reincke, B.; Thöny-Meyer, L.; Dannehl, C.; Odenwald, A.; Aidim, M.; Witt, H.; Rüterjans, H.; Ludwig, B. Heterologous Expression of Soluble Fragments of Cytochrome $c_{552}$ Acting as Electron Donor to the Paracoccus denitrificans Cytochrome c Oxidase. Biochim. Biophys. Acta 1999, 1411, $114-120$.
35. Franck, E. U.; Deul, R. Dielectric Behaviour of Methanol and Related Polar Fluids at High Pressures and Temperatures. Faraday Discuss. Chem. Soc. 1978, 66, 191-198.

36. Dessiaterik, Y.; Nguyen, T.; Baer, T.; Miller, R. E. IR Vaporization Mass Spectrometry of Aerosol Particles with Ionic Solutions: The Problem of Ion-Ion Recombination. J. Phys. Chem. A 2003, 107, 11245-11252.

37. Moller, J. V.; le Maire, M. Detergent Binding as a Measure of Hydrophobic Surface Area of Integral Membrane Proteins. J. Biol. Chem. 1993, $268,18659-18672$.

38. Seddon, A. M.; Curnow, P.; Booth, P. J. Membrane Proteins, Lipids and Detergents: Not Just Soap Opera. Biochim. Biophys. Acta 2004, 1666 105-117.

39. Garavito, R. M.; Ferguson-Miller, S. Detergents as Tool in Membrane Biochemistry. J. Biol. Chem. 2001, 276, 32403-32406.

40. Richter, O.-M. H.; Ludwig, B. Cytochrome $c$ Oxidase-Structure, Function, and Physiology of a Redox-driven Molecular Machine. Rev. Physiol. Biochem. Pharmacol. 2003, 147, 47-74.

41. Hosler, J. P.; Ferguson-Miller, S.; Mills, D. A. Energy Transduction: Proton Transfer through the Respiratory Complexes. Annu. Rev. Biochem. 2006, 75, 165-187.

42. Witt, H.; Ludwig, B. Isolation, Analysis, and Deletion of the Gene Coding for Subunit IV of Cytochrome $c$ Oxidase in Paracoccus denitrificans. J. Biol. Chem. 1997, 272, 5514-5517.

43. Ludwig, B.; Grabo, M.; Gregor, I.; Lustig, A.; Regenass, M.; Rosenbusch J. Solubilized Cytochrome $c$ Oxidase from Paracoccus denitrificans is a Monomer. J. Biol. Chem. 1982, 257, 5576-5578.

44. Mayer, G.; Anderka, O.; Ludwig, B.; Schubert, D. The State of Association of the $b c_{1}$ Complex from Paracoccus denitrificans in Solutions of Dedecyl Maltoside. Prog. Colloid Polym. Sci. 2002, 119, 77-83.

45. Hunte, C.; Koepke, J.; Lange, C.; Rossmanith, T.; Michel, H. Structure at $2.3 \AA$ Resolution of the Cytochrome $b c_{1}$ Complex from the Yeast Saccharomyces cerevisiae Co-crystallized with an Antibody Fv-Fragment. Structure 2000, 8, 669-684.

46. Kurowski, B.; Ludwig, B. The Genes of the Paracoccus denitrificans $b c_{1}$ Complex-Nucleotide Sequence and Homologies between Bacterial and Mitochondrial Subunits. J. Biol. Chem. 1987, 262, 13805-13811.

47. Elberry, M.; Xiao, K.; Esser, L.; Xia, D.; Yu, L.; Yu, C. A. Generation, Characterization and Crystallization of a Highly Active and Stable Cytochrome $b c_{1}$ Complex Mutant from Rhodobacter sphaeroides. Biochim. Biophys. Acta 2006, 1757, 835-840.

48. Berry, E. A.; Huang, L.-S.; Saechao, L. K.; Pon, N. G.; ValkovaValchanova, M.; Daldal, F. X-ray Structure of Rhodobacter capsulatus Cytochrome $b c_{1}$ : Comparison with Its Mitochondrial and Chloroplast Counterparts. Photosynth. Res. 2004, 81, 251-275.

49. Berry, E. A.; Guergova-Kuras, M.; Huang, L.-S.; Crofts, A. R. Structure and Function of Cytochrome bc Complexes. Annu. Rev. Biochem. 2000, $69,1005-1075$

50. Stroh, A.; Anderka, O.; Pfeiffer, K.; Yagi, T.; Finel, M.; Ludwig, B.; Schägger, H. Assembly of Respiratory Complexes I, III, and IV into NADH Oxidase Supercomplex Stabilizes Complex I in Paracoccus denitrificans. J. Biol. Chem. 2004, 279, 5000-5007.

51. Howlett, G. J.; Minton, A. P.; Rivas, G. Analytical Ultracentrifugation for the Study of Protein Association and Assembly. Sci. Direct 2006, 10, $430-436$. 